\title{
Perceived factors influencing academic performance of students in accounting in secondary schools in Anambra State.
}

\author{
Obidile Jacinta Ifeoma, Amobi Stella Chinyere, Uzoekwe Helen Efeyadu and \\ Akuezilo Juliana A. \\ Nnamdi Azikiwe University, Awka
}

\begin{abstract}
The study sought to find out factors that affect students' academic performance in accounting in public secondary schools in Anambra State. Two research questions guided the study and two null hypotheses were formulated and tested at 0.05 level of significance. Population of the study comprised 5,389 accounting students. Simple random sampling was used to select 845 accounting students as sample for the study. The instrument for data collection was a structured questionnaire validated by three experts with a reliability coefficient of 0.81. Data collected were analyzed using mean for the research questions and z-test for testing the null hypotheses. Findings revealed that institutional and socio-economic factors affect students' academic performance. Also there was no significant difference in the mean ratings of male and female accounting students on the perceived institutional and parental socio-economic factors that affect their academic performance in accounting. Based on the results of the findings, it was concluded that institutional factors and parental socio-economic factors (especially educational level and occupational status of parents) are among the factors influencing students' academic performance in accounting. Consequently, it was recommended among others that school administrators should provide enough time for the teaching and learning of accounting. Also parents/guardians should always encourage their wards by equipping them with the necessary materials needed to study accounting.

Keywords - Accounting, Academic performance, Secondary schools, Gender, Perceived factors.
\end{abstract}

\section{INTRODUCTION}

There is underlying complexity of the factors affecting the performance of students in education attainment and this is what has prompted the current study. Despite the complexity of factors influencing students' achievement, a number of studies are pointing to the evidence that institutional factors are associated with academic performance though mainly in other subjects rather than accounting. Accounting is one of the subjects needed by every individual irrespective of the person's profession. For any business to thrive, the knowledge of accounting is necessary. Accounting is concerned with the acquisition of knowledge for recording, analyzing, interpreting and summarizing the financial data of an organization or enterprise (Ndinechi \& Obidile, 2013). Unfortunately students' performance in the subject has not been encouraging especially at the post basic education level (secondary schools). Post basic education level is the level between the basic and tertiary level where systematic and organized education is offered. It is believed that at this level of education, desired attitude, skill and knowledge could be obtained by the recipients. Information gathered from post primary school service commission (PPSSC), Awka showed a decline in the performance rate of students in accounting in external examination from $2013-2015$ as $40 \%, 36 \%$ and $32 \%$ respectively. Academic performance according to Eze, Ezenwafor and Obidile (2016) is the outcome of students' effort in examinations. It was observed from the literature that students' academic performance is determined by a number of factors.

\section{Literature Review}

A number of studies have been carried out to identify and analyse the numerous factors that affect academic performance in various levels of educational attainment. Their findings identified change of school, family break up, teacher absence, parent illness and death of a family member, student's illness, learning disability caused by visual or hearing impairment and student's attitude towards learning as causes of poor academic performance (Browny \& Sunniya, 2002). Others include shortage of well-trained teachers, inadequacy of teaching facilities, lack of funds to purchase necessary equipment, poor quality textbooks, large classes, poorly motivated teachers, lack of laboratories and libraries, poorly coordinated supervisory activities, interference of the school system by the civil service, incessant transfers of teachers and principals and automatic promotion of pupils (Vundla, 2012). Mbugua, Kibet, Muthaa and Nkonke (2012) listed factors as under staffing, inadequate teaching/learning materials, lack of motivation and poor attitude by both teachers and students as factors influencing academic performance of students. 
Igwe and Ikatule (2011) attributed poor academic performance of students to deficiency in teaching method(s) used by teachers. According to Tshabalala and Ncube (2013) lack of materials, bad teacher behavior, poor grounding in the subject area at lower levels, poor teaching methods as well as fear of the subject are factors affecting academic performance of students. Enu, Agyman and Nkum (2015) listed the causes of academic performance to include inadequate teaching and learning materials, method of instruction, teachers and students' self-motivation. Specifically, in accounting, academic performances of students are influenced by related factors such as negative attitude of students towards accounting as a difficult subject, students' academic aptitude, previous and recent academic performances, insufficient effort and poor motivation (Atieh, 2013). Also teachers' qualification and experience affect academic performance of students in accounting (Omotayo, 2014). According to Okon (2002) poor application of teaching methods, lack of fund, inadequate teaching experience, lack of teaching aids, lack of qualified teachers and wrong methods of teaching could influence students' interest in accounting. Igberi (1999) mentioned unavailability of current text-books in accounting as one of the causes of poor academic performance of students in accounting. Corroborating, Ezeagba (2014) listed inadequate instructional materials and ineffective/poor teaching method as causes of poor students' academic performance in accounting. Ward, Wilson and Ward (1994) attributed causes of students' poor academic performance in accounting to lack of study, inability to apply the material covered, the speed of coverage of the material, the method used by the instructor, among others. However most of these studies were conducted in different environment rather than the environment of the present study. Hence the need to identify the factors influencing students' academic performance in accounting in secondary schools in Anambra State.

\section{Research Questions}

The following research questions guided the study:

1. What institutional factors affect students' academic performance in accounting?

2. What parental social economic factors affect students' academic performance in accounting?

\section{Null Hypotheses}

The following null hypotheses were formulated and tested at 0.05 level of significance.

1. There is no significant difference in the mean ratings of male and female accounting students on the perceived institutional factors that affect their academic performance in accounting.

2. There is no significant difference in the mean ratings of male and female accounting students on the perceived parental social economic factors that affect their academic performance in accounting.

\section{Method}

The study employed a survey research design. Anambra State was the area of the study. The population of the study consisted of 845 Senior Secondary (SS) II accounting students (485 males and 360 females). Simple random sampling was used to select 845 SS II students as the sample. The instrument for data collection was a fourteen-item questionnaire constructed by the researchers after extensive review of literature. The instrument was validated by three experts. Reliability of the instrument was determined using cronbach alpha's method which yielded a reliability coefficient of 0.81 . The instrument was divided into two sections. Section A sought the background information of the respondents and Section B contained 14 items. Data collected were analyzed using mean scores to answer the research questions and z-test to test the null hypotheses at 0.05 level of significance.

\section{Findings}

Table 1: Respondents' mean rating on the institutional factors that affect academic performance in accounting

$\mathrm{N}=845$

\begin{tabular}{|c|c|c|c|}
\hline & \multicolumn{3}{|c|}{$\mathbf{S} / \mathbf{N}$} \\
\hline \multicolumn{2}{|c|}{ Institutional factors } & Remarks & \\
\hline 1 & Inadequate textbook for study & 3.58 & Agreed \\
\hline 2 & Inadequate number of teachers & 3.55 & Agreed \\
\hline 3 & Inadequate libraries & 3.57 & Agreed \\
\hline 4 & Ineffective teaching method & 3.50 & Agreed \\
\hline 5 & Teachers' attitude towards accounting & 3.52 & \\
\hline 6 & Speedy coverage of the materials & 3.76 & \\
\hline 7 & Class size & & Agreed \\
\hline
\end{tabular}


$8 \quad$ Inappropriate entry requirements for

Accounting class

$9 \quad$ Inadequate time for teaching

accounting

10 Inexperienced teachers to

handle the subject
3.53

3.45
Agreed

Agreed

3.42

Agreed

The data shown in Table 1 reveal that the ten items had their mean ranging from 3.42-3.76 which shows that the ten items were considered as institutional factors affecting students' academic performance.

Table 2: Respondents' mean rating on parental socio-economic factors that affect academic performance in accounting

$$
\mathrm{N}=845
$$

\begin{tabular}{|c|c|c|c|c|c|c|c|}
\hline \multirow[b]{2}{*}{1} & $\mathbf{S} / \mathbf{N}$ & \multicolumn{3}{|c|}{ Parental socio-economic factors } & & \multirow[t]{2}{*}{$\mathbf{X}$} & \multirow[t]{2}{*}{ Remarks } \\
\hline & Educational 1 & vel of parents & & & 3.57 & & \\
\hline 2 & Occupational & tatus of parents & & & 3.50 & & \\
\hline 3 & Income level & f parents & 2.40 & & & & agreed \\
\hline 4 & Parental statu & in the society & & 2.30 & & & agreed \\
\hline
\end{tabular}

Data in Table 2 reveal that two items had their mean ranging from 3.50-3.57 which shows that the items were considered as parental socio-economic factors affecting students' academic performance. Also, the other two items had their mean ranging from 2.30-2.40 which shows that the items were not considered as parental socio-economic factors affecting students' academic performance.

Table 3: The $\mathrm{z}$ test result on the effect of gender on respondents' consideration of institutional factors

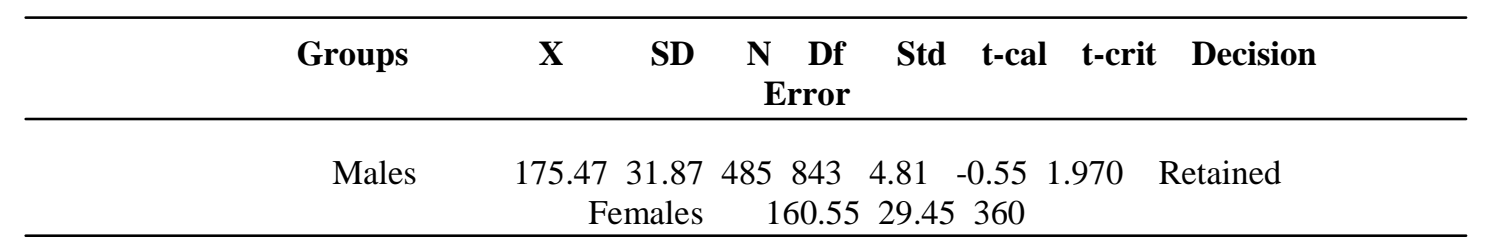

Results from Table 3 of the z-test analysis show that the calculated $\mathrm{z}$ value of -0.55 is less than the critical $\mathrm{z}$ value of 1.970 at 0.05 level of significance. This implies that there is no significant difference in the mean ratings of male and female students in their consideration of institutional factors.

Table 4: The $\mathrm{z}$ test result on the effect of gender on respondents' consideration of parental socio-economic factors

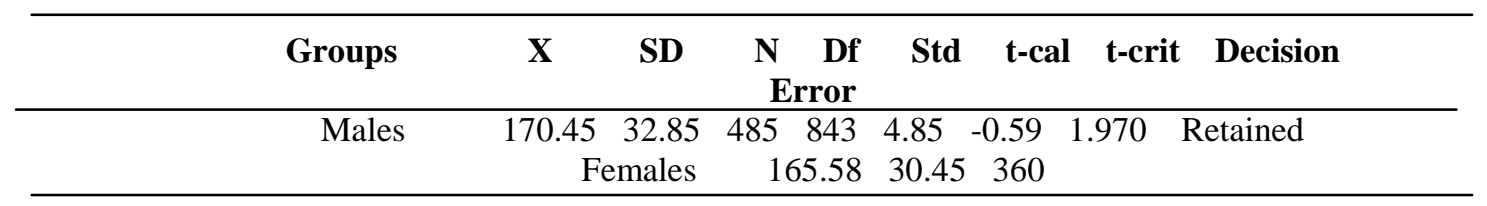

Results from Table 4 of the z-test analysis show that the calculated $z$ value of -0.59 is less than the critical $\mathrm{z}$ value of 1.970 at 0.05 level of significance. This implies that there is no significant difference in the mean ratings of male and female students in their consideration of parental socio-economic factors.

\section{DISCUSSION}

Findings of the study which was analyzed and presented in Table 1, show that accounting students considered institutional factors such as inadequate texts, Inadequate number of teachers, inadequate libraries, ineffective teaching method, teachers' attitude towards accounting , speedy coverage of the materials, class size, Inappropriate entry requirements for accounting class, Inadequate time for teaching for teaching accounting and inexperienced teachers to handle the subject as factors affecting academic performance of students in 
accounting. This is in line with the findings of Igwe and Ikatule (2011) which revealed that institutional factors affect academic performance of students. This implies that institutional factors which affect academic performance of students are related. Findings in Table 2 show that there is no significant difference in the mean ratings of male and female accounting students' consideration of institutional factors. This shows that the respondents' consideration of institutional factors as factors affecting their performance was not as a result of gender. Findings of the study which was analyzed and presented in Table 3, show that accounting students considered parental socio-economic factors (educational level of parents and occupational status of parents) as factors affecting academic performance of students in accounting. This is in line with the findings of Enu, Egyman and Nkum (2015) which revealed that parental socio-economic factors affect academic performance of students. This finding contradicts the findings of Singh and Singh (2014) which revealed that the socioeconomic status of parents does not affect students' academic performance.

Also, findings in Table 4 show that there is no significant difference in the mean ratings of male and female accounting students' consideration of parental socio-economic factors. This shows that the respondents' consideration of parental socio-economic factors as factors affecting their performance was not as a result of gender.

\section{CONCLUSION}

From the findings of the study, it is therefore concluded that institutional factors and parental socioeconomic factors (educational level and occupational status of parents) affect students' academic performance in accounting.

\section{RECOMMENDATION}

From the findings of the study. It is therefore recommended that, school administrators should provide enough time for the teaching and learning of accounting. School administrators should ensure that adequate class size is maintained, to enhance students' academic performance in accounting. Parents/guardians should always encourage their wards by equipping them with the necessary materials needed to study accounting.

\section{REFERENCES}

[1] Atieh, S. H. (2013). Student perceptions of the causes of low performance in principles of accounting: A case study in Saudi Arabia. JKAU: Economics and Administration, 10, 35-50.

[2] Browny, E. B. \& Sunniya, S. L. (2002). Social-emotional facts affecting achievement outcomes using disadvantaged students: Closing the achievement gap. Educational Psychology, 15, 28-36.

[3] Enu, J, Agyman, O. K., \& Nkum D. (2015). Factors influencing students' mathematics performance in some selected colleges of education in Ghana. International Journal of Education Learning and Development, 3(3), 68-74.

[4] Eze, Ezenwafor \& Obidile (2016). Effects of problem-based teaching method on students academic performance and retention in financial accounting in technical colleges in Anambra State. Online Scholars Journal of Arts, Humanities and Social Sciences, 4(6A), 634-639.

[5] Ezeagba, C. E. (2014). Problems in the teaching and learning of accounting as a vocational subject in Nigeria secondary schools. International Journal of Science and Technology, 3(2), 208-226.

[6] Igberi, R. O. (1999). Financial Accounting Made Simple. Lagos: ROI

[7] Igwe, A. U. \& Ikatule, O. R. (2011). Effects of computer tutorial and drill (CTD) on senior secondary school students' achievement in basic electronics in Lagos State. Proceedings of Nigerian Association of Teachers of Technology. Umunze, 108-119.

[8] Mbugua, Z. K., Kibet, K., G., Muthaa, G. M. \& Nkonke, G. R. (2012). Factors contributing to students' poor performance in Mathematics at Kenya certificate of secondary education in Kenya: A Case of Baringo County, Kenya. American International Journal of Contemporary Research, 2(6), 5-10.

[9] Ndinechi, G. I. \& Obidile, I. J. (2013). Strategies considered effective for teaching accounting in tertiary institutions in Anambra State. The Official Journal of Nigerian Accounting Association (NAA), 4(2), 133-143.

[10] Okon, E. C. (2002). Strategies for improving students interest in accounting in secondary schools in Akwa Ibom State. Unpublished Masters Thesis. University of Nigeria, Nsukka.

[11] Omotayo, B. K. (2014). Teachers' characteristics and students' performance level in senior secondary school financial accounting. Journal of Empirical Studies, 1(2), 48-53.

[12] Singh, A. \& Singh, J. P. (2014). The influence of socio-economic status of parents and home environment on the study habits and academic achievement of students. Educational Research, 5(9), 348-352.

[13] Tshabalala, T. \& Ncube, A. C. (2013). Causes of poor performance of ordinary level pupils in mathematics in rural secondary schools in Nkayi District. Nova Journal of Medical and Biological Sciences, 1(1), 4-14.

[14] Vundla, B. (2012). School Curriculum. Pretoria: North.

[15] Ward, S. P., Wilson, T. E. \& Ward, D. R. (1994). Students' assessments of factors contributing to failure in the first accounting course. Psychological Reports, 75(1), 29. 